\title{
Essayet og ulykken
}

\author{
En afprøvning af Theodor W. Adornos og Erling Aadlands essayteori
}

\author{
BJARNe MarkusSEN
}

En kort redegørelse for Adornos og Aadlands essayteori Der er mange måder at nærme sig essayet som genre på. Man kan gøre det socialhistorisk (essayet som et renæssanceprodukt) eller stilhistorisk (essayet som en sprængning af antikkens stilsystem), man kan udarbejde en topik (essayet som en dialogisk, processuel og kritisk form) eller man kan arbejde filosofisk med spørgsmålet om essayet som en særegen forståelseform. ${ }^{\text {I }}$ Dette sidste er det Theodor W. Adorno tenderer mod $\mathrm{i}$ det kendte meta-essay „Essayet som form“ fra 1958. Den norske litteraturforsker Erling Aadland gør det også, som en af de få (den eneste?) der har taget til orde mod Adornos måde at bestemme essayet teoretisk. Artiklen „Essayet som meta-essay“ fra 1982, trykt $\mathrm{i}$ antologien Essayet $i$ Norge, er en kritisk gennemgang af Adornos tekst og et forsøg på at give essayet et andet teoretisk fundament. ${ }^{2}$ Fordi: „En genrelære kan kun baseres på en forståelsesform som er sikret en teoretisk autonomi." (Aadland I982: 225)

Denne artikel har ingen pratentioner som at lodde de filosofiske dybder i Adornos og Aadlands teorier. Trods mange lighedspunkter er afstanden stor mellem de teoretiske positioner. Adornos tekst er blandt andet et angreb på ontologien, Aadlands tekst et forsvar. Denne artikel vil give en kort redegørelse for teorierne og derefter afprøve den afgrænsning mellem essayet og andre former (kunst og teori) som fremkommer hos Adorno og Aadland. Afprøvningen foretages gennem en læsning af to essays af Michel de Montaigne: „At filosofere er at lære at $\mathrm{d}^{\circ}$ “ og „,Om at føle sorg“.3 Konfrontationen mellem essay og essayteori skal vise at essayet som form har potentiale til at overskride både Adornos og Aadlands definitioner, og at det er denne overskridende evne, der gør det så vanskeligt at forstå hvad essayet $e r$.

Det må præciseres at forskellen mellem Adorno og Aadland ikke ligger så meget $\mathrm{i}$ afgrænsningsproblemet, som i begrundelsen for en grænsedragning. Aadland accepterer langt hen ad vejen Adornos karakteristik af essayet og dets erfaringsbegreb, men skriver at Adornos (og Georg Johannesens) position „trænger til et ontologisk 'fundament' for at blive teoretisk gyldig.“ (I982: 225-226) 4 Han mener ikke at essayet kan væsensbestemmes gennem et andet essay, fordi en sådan teoretisk virksomhed må overskride essayets egen subjektive og kulturkritiske erfaringshorisont. Essayet kan ikke forstå essayet til bunds: „Meta-essayet er essayets længste kommen hjem til sig selv, men for at essayet skal komme hjem, må det overgive sig til den rene teoretiske spørgen." (1982: 226) Svagheden ved Adornos position (i den forstand at hans meta-essay har teoretiske prætentioner) er derfor den essayistiske, antiontologiske holdning. Et svaghedspunkt hos Aadland er imidlertid at han lader Adornos karakteristik af essayet få så stor autoritet. Det bliver uklart om hans teori er en 'selvstændig' teori om essayet, eller en underbygning af Adornos teori. Adornos ideologikritiske indsnævring af essayets arbejdsområde lader til at forplante sig videre.

Lettere forenklet kan man sige at mens Adorno forankrer essayformen $i$ et erkendelsesmæssigt forhold, hvor sproget spiller den centrale rolle som formidlende instans, så søger Aadland essayets grundlag $\mathrm{i}$ 
en aristotelisk antropologi, hvor fornuftsbegrebet deles. Hos Adorno er det bevidstheden om ikkeidentitet mellem det fremstillede og fremstillingen som er essayets berettigelse og sag. Hos Aadland bestemmes essayet som den praktiske fornufts ytringsform. Essayet er funderet i den livsform Aristoteles kalder bios politikos.

Adorno afgrænser essayet mod kunsten på den ene side, og mod videnskaben og en evighedsorienteret filosofi (,,auf Ewigkeitswerte geeichten Philosophie"), som tydeligvis også inkluderer fænomenologien, på den anden side. I én forstand viderefører Adorno den traditionelle placering af essayet mellem kunst og videnskab. Men han sprænger samtidig det erkendelsesteoretiske grundlag for denne opdeling: emotio/ratio-distinktionen som skiller essayet ud som noget urent og substansløst. Når essayet undgår videnskabelige kategorier og metoder, skyldes det ifølge Adorno netop en begrundet mistro til et traditionelt sandhedsbegreb (overensstemmelse mellem sag og påstand).

Essayet ligner kunsten ved at det arbejder ,emfatisk med sin fremstillingensform" (1992: 35). 5 Det har affinitet til billedet og det intrikate netværk af begreber. Som kunsten vil det synliggøre det som ideologien holder skjult, det vil tolke det frem som videnskaben og den traditionelle teori holder skjult. Men essayet adskiller sig fra kunsten ved at bruge begreber.

På dette punkt ligner essayet teori. Men essayet adskiller sig fra teori i måden begreberne bruges på. Begreberne defineres ikke, de indføres umiddelbart og deres mangetydighed udnyttes. De udgør ikke en række operationer, men flettes sammen som trådene i et tæppe. „Egentlig tænker den tænkende slet ikke, men gør sig selv til skueplads for åndelig erfaring." (1992: 3I ${ }^{6}$ Emnet analyseres ikke del for del, det behandles i sin fulde kompleksitet. Essayet er antisystematisk og bryder med videnskabens metodebegreb. Det særegne ved essayet er at bevidstheden om ikke-identitet bibeholdes både $\mathrm{i}$ form og indhold:
Dets form stemmer overens med dén kritiske tanke at mennesket ikke er nogen skaber, at intet menneskeligt er skabelse.Det fører sig hverken selv - henvist som det altid er til noget $i$ forvejen skabt - frem som skaberværk, ejheller stræber det efter noget altomfattende, hvis totalitet kunne sammenlignes med skabelsens. Essayets totalitet - den enhed der tilkommer en indadtil gennemkonstrueret form - er det ikke-totales totalitet, der heller ikke som form hævder den tese om identiteten af tanke og genstand, som den i sit indhold forkaster. (r992: $35)^{7}$

Ifølge Adorno lider videnskaben af den overtro at ideernes orden tilsvarer tingenes orden. Dens arbejde er ordnende og indordnende, og den reproducerer derfor de rådende samfundsforhold. Den evighedsorienterede, storslåede filosofi lider til gengæld af den overtro at den kan gribe totaliteten og trænge ind til de oprindelige fænomener, det uformidlede. Men det oprindelige må begribes gennem begrebet om det. Man kommer ikke uden om formidlingen, og den er præget af sproget og kulturen. Egentlighedens jargon er falsk tale.

Essayet gør, ved sin blotte handling, op med den illusion at tanken skulle kunne bryde ud af det som er $\tau \eta \in \sigma \in \iota$, kultur, over i det som er $\pi \eta v \sigma \epsilon l$, af natur. Bundet som det er af det fixerede, til det indrømmet afledte, til det frembragt, holder det naturen i ære ved at bekræfte at den er hvad mennesket ikke længere er. Dets alexandrinisme tager højde for at syrenen og nattergalen endnu, dér hvor det universelle net tillader dem en form for overlevelse, ved deres blotte existens kan give det indtryk at livet endnu var i live. (I992: 29) ${ }^{8}$

Essayets arbejde er kritisk og sandhedsbærende, kættersk. Dets sandhed består $i$ at arbejde sig gennem det usande, fremvise ikke-identiteten, snarere end at postulere en natur eller totalitet. „Essayet æder de teorier op som står det nærmest; det stræber altid mod den faste menings likvidering - også den hvori det selv tog afsæt." (I992: 36)9 Dette arbejde foretages gennem en indtrængende subjektiv fortolkning af virkeligheden. Forbilledet er den åndelige erfaring. Essayets sandhed er knyttet til en enkeltmenneskelig erfaringssammenhæng, til den dannede individuelle bevidsthed. Kun gennem ,det 
indtrængende subjektive udtryk" (des eindringen den subjektiven Ausdrucks) kan essayet overliste „den diskursive logik“, få tingene i tale og bidrage til realiseringen af frihed og lykke, som er dets inderste mål. Den subjektive erfaring og bevidstheden om ikke-identitet er ifølge Adorno essayets forudsætninger.$^{10}$ Essayet er subjektiv fortolkning, gestaltning over det gestaltede: „Det er, og var fra første færd, den kritiske for par exellence, og mere præcist - som immanent kritik af åndelige frembringelser, som konfrontation af disse med deres begrb - ideologikritik.” (I992: 36) ${ }^{\mathrm{II}}$

Således afgrænser Adorno essayet mod kunsten, videnskaben og den „evighedsorienterede filosofi“. Ikke nok med det. Kritikken af den traditionelle tænkning er så hårdtslående, at den kun efterlader den oprørske kunst og essayet som virkelig sandhedssøgende virksomheder. Hermed er det nærliggende at se også kritisk teori som et essayistisk virke, som en alternativ teoretisk tænkemåde. Men samtidig fremgår det at essayet ernærer sig af (,fortærer“) andre teorier. Essayet lever altså $i$ et produktivt spændingsforhold til traditionel teori.

Aadland stiller i sin artikel spørgsmålet om forholdet mellem essay og essayteori, og mener at dette er uafklaret hos Adorno. Den kultursociologiske ansats i kritisk teori spærrer for ontologiske problemstillinger, spørgen efter genstandens (f.eks. essayets) væsen:

selv om essayet altid vil vere forpligtet på subjektiv menneskelig erfaring, så kan essayteorien ikke vere det samme. Ikke at se denne væsentlige forskel - det er den skæbnesvangre fare Adorno har udsat os for. Han narrer os langt ind i en tænkemåde som underminerer al traditionel europæisk spørgen efter de sidste årsager. (I982: 226)

Teoretisk placerer dette sig $\mathrm{i}$ et ambivalent forhold til totalitetskategorien. Adorno afviser totaliteten som en naturbeherskende tankemodus, men vil alligevel ikke afvise den helt. Totaliteten skal „glimte“ i essayet. Essayets form er en total ikke-totalitet, som forlader vejen mod det oprindelige uden at ideen om det umiddelbare helt forsvinder. Når Adorno skriver at essayets koncentration omkring formidling giver grund til at tro at livet endnu lever, så lever totalitetskategorien også videre som „længsel og poetisk substrat", skriver Aadland (1982: 218).

Når alt mellem himmel og jord er formidlet, er det selve formidlingen som udgør totaliteten. Spørgsmålet om et overordnet sprogbegreb, som kan indfange denne totale formidling, presser sig på. Hvis sproget er den formidlende totalitet, sådan som den sene Heidegger synes at mene, er det klart at tænkningens sag altid er en sproglig sag. Allerede Parmenides hævdede at sprog og tanke er det samme. Ontologisk set er det sandt at sprog, tanke og sag er det samme. Fra et rent teoretisk synspunkt synes det fornuftigt at acceptere Husserls eidetiske reduktion (og sætte den objektivistiske tese i parentes), for at udspørge betydningerne. Men hverken Adorno eller essayet går den spørgende vej. (1982: 219-220)

Med denne indvending opnår Aadland (mindst) tre ting. For det første afslører han en manglende vilje hos Adorno til at forfølge påtrængende spørgsmål om formidlingens status, om ikke-identitet som et alment vilkår for tænkning. For det andet synliggøres en forskel mellem essayet og fænomenologien som forståelsesformer. Essayet kan ikke give slip på forpligtelsen overfor den faktiske virkelighed. Et ontologisk essay bliver utænkeligt: „Et eventuelt ontologisk essay vil medføre at essayteorien ikke kan trække andre skillelinier, mellem for eksempel afhandlingen og essayet, end sådanne som udspringer af trivielle forskelle af typografisk eller publikationsteknisk art.“ (I982:224) Essayet er gestaltning over det gestaltede, men ontologi er gestaltning over det gestaltedes gestaltning. For det tredje afvises tanken om at bevidstheden om ikke-identitet (eller formidlingens rolle) er forbeholdt essayet. Hermed kan bevidstheden om ikke-identitet ikke afgrænse essayet fra ontologien: „Også i ontologien foregår der et intenst arbejde med udtrykket. Nietzsches skrifter, som kritikken i al sin forlegenhed kalder digterfilosofiske, kan tjene som eksempel på dette.“ (1982: 224) 
Men hvis ikke bevidstheden om ikke-identiteten mellem genstand og udtryk kan afgrænse essayet fra ontologien, hvori består forskellen så? Her forsøger Aadland en anden udvej - at forankre essayet i noget ikke-sprogligt. Han vender sig mod Aristoteles, som skelner mellem en ren og en praktisk fornuft. „Den rene fornuft tænker det som er (ontologi), og den praktiske fornuft tænker det som skal frembringes og virkeliggøres. Den er altså tæt forbundet med den menneskelige frihed." (1982: 226) Den praktiske fornuft er knyttet til livsformen bios politikos, det praktiske handlende menneske som arbejder for det fælles bedste. Den rene fornuft er knyttet til livsformen bios theoretikos, tænkningens liv. Det er i den praktiske fornuft (og i livsformen bios politikos) grundlaget for essayet findes. Den praktiske fornuft forholder sig til det som kunne være anderledes. En praktisk sandhed (aletheia praktike) er målet for den praktiske fornufts arbejde. Den viden om den praktiske sandhed, som er nødvendig for at det gode liv kan nåes, kalder Aristoteles for fronesis. Det er en handlekraftig viden.

Fronesis er viden om sandhed og den fornuftige sjæledels dyd, i den grad denne er praktisk orienteret.[...] Sofia er den fornuftige sjæledels dyd i den grad denne er teoretisk.

Med begrebet fronesis er man tæt på essayets kerne. Den græske tænkning har uddybet det erfaringsbegreb som Adorno baserer essayet på. Essayets arbejde er et fornuftsarbejde, og dets virke er sandhedsbærende. Men fornuften i essayet er en praktisk fornuft og sandheden er en praktisk sandhed. Essayets sande arbejdsområde er derfor statsdannelse og politik. Mennesket vil altid være et centrum i essayet, ikke som handlende, men som vidende om at handle. Fordi den fronesis som virker i essayet har sit mål i menneskelig lykke og frihed. Essayet er derfor humanistisk i sit inderste væsen. (I982: 227228)

På dette grundlag fằ vi en medeling af formerne, der er parallel med Adornos afgrænsning: Digtning - Essaystik - Teori. Men essayet afgrænses nu i forhold til teorien ved at det er praktisk orienteret, det vil sige at det forholder sig til det som kunne have været anderledes, og ikke til værens sandhed. Omsorgen for fremtiden er essayets moral. I artiklen
„Prolegomena til Kinck“ skriver Aadland at „det som først og fremmest 'er' $i$ staten, er muligheden for forandring.“ (1982: 82) Essayet kan ikke sætte den faktiske virkelighed i parentes. Det spørger ikke efter „de sidste årsager“. Det er forpligtet over for en allerede etableret politisk horisont. Denne forpligtelse afgrænser også essayet fra kunsten, som i denne forstand er autonom - ihvert-fald i princippet: „Den kunstneriske autonomi består i friheden til at overskride virkeligheden“, lyder der i „Prolegomena til Kinck“" (1982: 83)

Hvis denne korte redegørelse for teorierne er nogenlunde dækkende, kan man sige at mens Adornos essayteori har en sprogfilosofisk og erkendelsesteoretisk forankring, så baserer Aadland essayet på en bestemt type erfaringssammenhæng og problemstilling. Begge forsvarer essayets kritiske og sandhedssøgende virke, men Aadland insisterer også på den „rene“ teoris fornuft. De er mere uenige om hvad teori er, end om hvad essayet er.

\section{To essays af Montaigne}

Kan leesningen sige os noget om essayet, efter disse tunge teorier? Montaignes essay „At filosofere er at lære at dø“ og „Om at føle sorg“, begge fra første bog af Essais (1580), handler om ting som i en forstand ligger fjernt fra det kulturelt frembragte. Hvilken slags sandhed er det vi præsenteres for om død og sorg?

I „At filosofere er at lære at dø“ er essensen at den som lærer at dø, lærer at leve. Det er et klassisk topos som Montaigne på god essayistisk manér varierer over. Essayet er gestaltning over det gestaltede, et overflødighedshorn af observationer, reflektioner, citater og anekdoter om døden og dens fremtrædelsesformer, et dødens raritetskabinet. Montaigne har „en særlig forkærlighed for dette emne“ (I992: Iro), han har altid døden i tankerne. At filosofere er at lære at slippe sin angst for døden. „For hvis ikke fornuften gør grin med os, må den udelukkende have det formål at gøre os glade og tilfredse og kort og godt sætte alt ind på at vi skal leve godt og have det rart, som der står i biblen.“ (I992: IOI). Hvis vi 
frygter tanken om døden ødelægger den livsglæden. At filosofere er at demaskere døden.

Døden er mindre frygtindgydende end ingenting, hvis der ellers var noget der var mindre end ingenting. [...] Den angår dig hverken død eller levende: levende fordi du er, død fordi du ikke længere er mere.[...] Hvor dit liv end slutter, så er der ikke mere, det var det hele. Udbyttet af livet har ikke noget med dets længde at gøre, men med hvordan man bruger det. (I992: IIS)

At ens død er værd at frygte, dét er den forestilling som for Montaigne er ikke-identisk med sagen, og som filosofien skal demaskere. „Lad os pille det fremmedartede af den [døden], lad os omgås den, lad os blive fortrolige med den. Der er intet vi så tit skal have i tankerne som døden.“ (1992: 107) „Børn blir bange, selv for deres kammerater, når de har maske på. Det samme gør vi. Vi må flå masken af både ting og mennesker.“ (1992: II7)

Filosofi er i denne sammenhæng en demaskerende virksomhed med et praktisk formål. Den skal hjælpe os til at leve det gode liv i staten. Montaigne holder døden på god afstand. „At filosofere er at lære at dø“ er tæt på at være et idealtypisk essay, både ud fra Adornos og Aadlands kriterier. Den dannede essayist forholder sig prøvende og indkredsende til sit enme, praktisk fornuftig til døden og ideologikritisk til gældende forestillinger om den. Essayet holder sig inden for teoriens rammer. Kun én ting skurer: Essayets længde. Over tyve sider fyldes med snak om døden. De mange citater røber desuden en omfattende læsning. Montaigne er besat af tanken om døden. Der kommer en uro til syne som bliver desto mere påfaldende, jo mere den dækkes af stoisk besindelse og epikuræiske besværgelser. Heri findes en indre spænding som kommer stærkere frem i „Om at føle sorg“.

„Om at føle sorg“ er et kort essay med en stram opbygning. Første og sidste afsnit udgør en personlig præget ramme, mens hoveddelen er en formel drøftelse af sorg og andre stærke følelser. Essayet er aty- pisk på to måder. For det første er Montaigne tavs om sine egne erfaringer, hvad han ellers ikke plejer. For det andet indledes essayet med en påfaldende krads afvisning af sorgen, ,en egenskab der altid er skadelig, altid vanvittig, og da den også altid er fej og foragtelig forbyder stoikerne helt deres vismænd at nære den." (1992: 35) ${ }^{\mathrm{I2}}$ Afslutningen er mere dæmpet. Her fortæller Montaigne at han sjældent er udsat for så stærke følelser, og at daglig filosoferen har gjort ham stadig mere hærdet.

Denne ramme er interessant, fordi den kradse afvisning står i kontrast til den indsigt Montaigne udviser i drøftelsen af sorg $i$ resten af essayet. ${ }^{13}$ Den er også interessant på en anden måde: Den var nemlig ikke med i førsteudgaven fra 1580 . Oprindeligt fandtes kun den upersonlige og mere filosofiske hoveddel. Afslutningen (plus indledningens forste sætning) kom med $\mathrm{i}$ andenudgaven fra 1588 , mens resten af indledningsafsnittet kun findes i Montaignes private eksemplar, det såkaldte Bourdeaux eksemplar. Måske var det tiltænkt en senere udgave. ${ }^{14}$ Montaigne har altså gennem en årrække vendt tilbage til dette essay med nye pointer: I sandhed et intenst arbejde med udtrykket. Og det som betones stærkere $\mathrm{i}$ revisionerne, foruden den distancerende holdning og kritikken af folk som bruger sorg til pynt, er netop spørgsmålet om udtrykket, nærmere bestemt umuligheden af at give udtryk for stærke følelser. Eller igen: Ikke-identiteten mellem sag og sprog.

Tematisk er dette essay tæt på essayet om døden. I alle anekdoterne drejer det sig om tabet af en søn eller en datter, den største af alle sorger. Og her bør der tilføjes en biografisk oplysning: Montaigne mistede selv fem ud af seks børn. Sagen er nærgående og man kunne tro at distancen til døden hermed blev mindre. Men det modsatte sker. Distancen markeres stærkere, indtil fornægtelse. Borte er talen om det gode liv, borte er den private fortrolighed. Den subjektive, ideologikritiske og praktiske orientering virker i bogstaveligste forstand påklistret: Den kom med i revisionen. Til gengæld er essayet blevet 
både mere filosofisk og mere kunstnerisk. Det overskrider essayteoriens bestemmelser.

Essayet kunne i mangel af bedre kaldes et udkast til en sorgens fænomenologi. I hvertfald drejer det sig om en tænkning som hovedsageligt ikke er praktisk orienteret. Det beskriver sorgens fremtrædelsesform, og perspektivet udvides således at det også omfatter andre stærke følelser. Det bevæger sig ikke så indcirklende som det forrige essay. Der er en klarere linie $\mathrm{i}$ tankeudviklingen. Pointerne uddybes gennem en række anekdoter som får karakter af eksempler. Og hovedpointen er at sorg (som andre stærke følelser) er sprogløs. En mat, stum og døv sløvhed lammer en. Sorgen ryster sjælen i sin grundvold og forhindrer den $i$ at handle frit, man kan til og med dø af sorg. Egypterkongen Psammenitos fortrak ikke en mine da hans søn bliv ført til henrettelse og hans datter blev gjort til tjenestepige hos perserkongen Kambyses, men river sig $\mathrm{i}$ håret $\mathrm{og}$ viser alle tegn på den allerstørste sorg da en af hans bekendte bliver ført bort. Det er kun den sidste sorg som kan udtrykkes gennem tårer, skriver Montaigne, „hvorimod de to første langt overskrider ethvert udtryksmiddel.“ (1992: 36) Kun ved at give efter for „tårer og klage“ kan sjælen falde til ro, gøre sig fri og genvinde sin ligevægt. Sorgen sætter så at sige bevidstheden ud af spillet, mens klagen fảr os til hægterne igen. Med et moderne udtryk kan man sige at sorgen er subjektopløsende og klagen subjektsamlende.

Montaigne bruger de eksemplariske anekdoter til at nærme sig sorgens karaktertræk, og det vigtigste er at sorgen ligger uden for sprogets område. Kan sorgen udtrykkes i sprog, er det ikke en sorg at tale om: „de små sorger fär male, de store er tavse.“ Det er paradoksalt at det er Seneca som citeres her, for det var jo netop med henvisning til stoikerne at sorgen blev afvist $\mathrm{i}$ indledningen. Her nærmer essayet sig - så vidt jeg kan se - ren teoretisk virksomhed, og det uden at forpligtelsen overfor den faktiske virkelighed ofres. Her fokuseres ikke-identiteten på et andet niveau. Det er ikke ikke-identiteten mellem sagen og folks opfattelse af den som er interessant.
Det interessante er den ikke-identitet som findes i sorgens egen natur, dette at fænomenet kendetegnes ved fraværet af et sprogligt korrelat. Essayet bevæger sig her i retning af det Adorno kalder den evighedsorienterede filosofi og det Aadland kalder den teoretiske livsform. Lige så meget kaldes det et „essay“ og således opleves det intuitivt.

Men det er samtidig lidt småtskårent at bare karakterisere „Om at føle sorg“ som sorgteori. Både indledningen og de stærke anekdoter antyder fortvivlelse og patos, en patos som rigtig nok afmonteres elegant $\mathrm{i}$ afslutningen, gennem den komiske anekdote om dialektikeren Diodoros, der døde af skam da han ikke kunne udrede et problem for sine studenter. Der er et foruroligende alvor over essayet. Det er næppe tilfældigt at Montaigne drøfter den kunstneriske fremstilling af sorg. Det vigtigste eksempel omhandler en af antikkens malere som skulle fremstille

den sorg, som de tilstedeværende følte ved ofringen af Ifigenia, på en sådan måde at det fremgik hvor nært knyttet hver af dem var til den smukke uskyldige pige, men som da han nåede til pigens far havde udtømt sine kunstneriske ressourser, hvorfor han malede ham med tildækket ansigt, som om intet minespil kunne udtrykke så overvældende en sorg. (I992: 36)

Faren males med tildækket ansigt. Kun indirekte, kun gennem forestillelse, kan sorgen få et udtryk. Ulykken kender intet andet navn end det negative. Heri ligger nøglen til at forstå Montaignes essay. Montaigne skriver med tildækket ansigt. Han, som selv har mistet et barn, imiterer maleren. Han tier om egne erfaringer og markerer afstanden fra den følelse, han reflekterer så indsigtsfuldt over $\mathrm{i}$ hoveddelen. Essayet selv er tårer og klage, i eftertænksomhedens besindige form. Dermed tenderer essayet ikke kun mod teori, men også mod kunst, mod lyrik. Essayet er lyrisk i den forstand at døden her er en konstant trussel, en katastrofe som fremstilles efter 'kunstens regler': med tildækket ansigt og tilkæmpet ro. Forestillelsen kan synes ironisk, men den er oppebåret af patos. Den filosofiske side af essayet holder distancen til døden gennem den demas- 
kerende reflektion, den lyriske side konfronteres med døden gennem den maskerende fremstilling. Forstillelsen bliver en trope, som i sidste ende vender talen om sorg væk fra både ideologikritikken og teorien.

Hvor den vender sig hen kan jeg ikke svare på. Men hvis det at fremstille sorg er to ting - både det at reaktivere sorgen, og det at få udløb for den - mødes to modstridende kræfter i fremstillingen, hvis Montaigne har ret. Sorgen er jo lammende (subjektopløsende), tårene og klagerne er frisættende (subjektsamlende). Denne strid foregår $i$ et rum som ligger uden for ideologikritikken og teorien, men som essayet trolig har til fælles med kunsten og klagesangen. Der er ikke nogen væsentlig forskel mellem Montaignes sorg-essay og for eksempel Jan Erik Volds sorg-digt „Levende mørke“:

Sorgen har ingen

bunn. Angsten har, kan du

finne

den - sorgen er når veggene

rundt ditt liv

skifter farge. Rembrant van Rijn

mistet kone

og tre barn, fra da av malte han

i brunt - mennesker

som så

ned. Ut av deres strømmer deres år

som levende mørke.

Hos Vold bliver sorgen også udtrykt indirekte gennem en anekdote som både tjener som digterisk billede og kunstnerisk forbillede. Lidt overraskende viser det sig at brugen af eksempler her forbinder essayet med både kunsten og teorien.

Hvis denne læsning holder stik, er den teoretiske konsekvens at essayet ikke kun er ideologikritik som låner karaktertræk fra kunsten og teorien, således som Adorno synes at mene. Dets fornuft forholder sig heller ikke kun til det som skal forandres, sådan som Aadland mener. Essayet kan også træde ind på både kunstens og teoriens egne områder. Gennem reflektion over faktiske og litterære eksempler, tenderer essayet mod teori. Ved at forholde sig til døden som konstant trussel og give dette forhold en form, tenderer essayet mod lyrik. Det er dette overskridende potentiale som gør det vanskeligt at forstå hvad essayet er.

Aadlands advarsel må dog alligevel tages til følge: Gør vi uden videre essayet til kunst og teori, nivellerer vi alle væsentlige forskelle, og så bliver essayet blot „tænkningens almene form.“ (1982: 224) Så langt vil jeg ikke gå. Der er en grænse for hvor langt essayet kan bevæge ind på teoriens og kunstens område før det slår over $i$ en anden form. Jeg vil fastholde at essayet ikke kan løses fra forpligtelsen overfor den faktiske virkelighed, det kan ikke blive helt autonomt. Men inden for denne ramme udviser essayet som form stor elasticitet. Muligheden for at essayet skal kunne forstå essayet står stadig åben.

På dansk ved Ole Bjarke Nielsen

Litteratur

Aadland, Erling: „Essayet som meta-essay“ og „Prolegomena til Kinck“" i Ottar Grepstad m.fl.: Essayet i Norge, Oslo 1982

Adorno, Theodor W.: „Der Essay als Form“ i Noten zur Literatur, Frankfurt 1989

Montaigne, Michel de: Essays. Første bog, Kbh. 1992

Montaigne, Michel de: Essayer. Bok 1, Stockholm 1986

Montaigne, Michel de: Essais 1, Paris 1969

Vold, Jan Erik: Sorgen. Sangen. Veien, Oslo 1987

Noter

I. Man kunne også tænke sig en semiotisk baseret essayteori, men det har jeg endnu ikke set.

2. Et klargørende og uddybende tillæg til denne teori findes i Aadlands artikel „Prolegomena til Kinck“ fra samme antologi. Jeg vil trække på enkelte momenter herfra.

3. På fransk: „De la tristesse“ og „Que philosopher, c'est apprendre à mourir“. Læsningen er baseret på den danske og svenske oversættelse. Jeg er hverken fransk filololog eller renæssanceforsker. Risikoen for fejltolkniner af ordenes betydninger er til stede. Når jeg alligevel bruger Montaignes tekster, er det fordi jeg tror at denne risiko ikke vil 
være udslagsgivende for de teoretiske pointer, som er de vigtige i denne sammenhæng.

4. Alle Aadland citater er angivet med henvisning til den norske udgave. o.a.

5. „Geschlossener aber ist der Essay, weil er an der Form der Darstellung emphatisch arbeitet." (Adorno I989: 26)

6. „Eigentlich denkt der denkende gar nicht, sondern macht sich zum Schauplatz geistiger Erfahrung, ohne sie aufzudröseln. “ (Adorno I989: 2 I) Alle danske oversættelser i teksten af Theodor W. Adorno henviser til "Essayet som form", på dansk ved Kasper Nefer Olsen, trykt andetsteds her i nummeret.

7. „Seine Form kommt dem kritischen Gedanken nach, dass der Mensch kein Schöpfer, dass nichts Menschliches Schöpfung sei. Weder tritt der Essay selbst, stets bezogen auf schon Geschaffenes, als solche auf, noch begehrt er ein Allumfassendes, dessen Totalität der der Schöpfung gliche. Seine Totalität, die Einheit einer in sich auskonstruierten Form, ist die des nicht Totalen, eine, die auch als Form nicht die These der Identität von Gedanken und Sache behauptet, die sie inhaltlich verwirft." (Adorno I989: 26)

8. „Der Essay kündigt wortlos die Illusion, der Gedanke vermöchte aus dem, was thesei, Kultur ist, ausbrechen in das, was physei, von Natur sei. Gebannt vom Fixierten, eingestandenermassen Abgeleiteten, von Gebilden, ehrt er die Natur, indem er bestätigt, dass sie den Menschen nicht mehr ist. Sein Alexandrinismus antwortet darauf, dass noch Flieder and Nachtigall, wo das universale Netz ihnen zu überleben etwa gestattet, durch ihre blosse Existenz glauben machen, das Leben lebte noch." (Adorno I989: I9)

9. „Er zehrt die Theorien auf, die ihm nah sind; seine Tendenz ist stets die zur Liquidation der Meinung, auch der, mit der er selbst anhebt." (Adorno 1989: 27)

Io. Dette er Aadlands observation og jeg tror den er rigtig. Aadland skriver: „Ikke-identitet begrunder sandhedsbegrebet $i$ essayet, og dermed også teori- og frihedsbegrebet. Men alle disse føjer sig ind under overbegrebet subjektiv erfaring." (1982: 216) Aadlands gennemgang af Adorno er klargørende på flere punkter.

II. „Er ist, was er von Beginn war, die kritische Form par excellence; und zwar, als immanente Kritik geistiger Gebilde, als Konfrontation dessen, was sie sind, mit ihrem Begriff, Ideologiekritik. “ (Adorno I989: 27)

12. På fransk lyder karakteristikken således: „Car c'est une qualité tousjours nuisible, tousjours folle, et, comme tousjours couarde et basse, les Stoïciens en defendent le sentiment à leurs sages.“ (Montaigne I969: 47) „Foragtelig“ er måske en lidt uheldig oversættelse af ,basse“. Den svenske oversætter vælger ,låg“. Andre medbetydeninger kunne være: uværdig, krybende, fej. Afvisningen af sorgen er ihvertfald påfaldende kategorisk.
13. Det er Arild Linneberg som i forelæsningssammenhæng har gjort mig opmærksom på denne kontrast, og at den har forbindelse til Montaignes egen tematisering af det kunstneriske udtryk. Den øvrige læsning og det teoretiske ræsonnement er mit eget.

I4. Den svenske Montaigne oversættelse fra 1986 ved Jan Stolpe gør ligesom den franske udgave fra 1969 rede for disse tilføjelser. 